\title{
A nata e as cotas raciais: genealogia de um argumento público
}

$\begin{array}{r}\text { João Feres Júnior } \\ \text { Verônica Toste Daflon } \\ \hline\end{array}$

\section{I ntrodução}

O debate público sobre as políticas de ação afirmativa com recorte racial, comumente conhecidas como cotas, mudou de patamar no ano de 2012, marcado pela derrota da Ação de Descumprimento de Preceito Fundamental 186 (ADPF 186) e pela sanção presidencial da Lei Federal 12.771. Por uma votação de 10 a 0 , o Supremo Tribunal Federal decidiu contra a ADPF 186 ajuizada pelo partido político Democratas contra o programa de ação afirmativa étnico-racial da Universidade de Brasília (UnB). A aprovação da Lei Federal 12.771, por sua vez, tornou obrigatória a reserva de vagas para pretos, pardos, indígenas, alunos de escola pública e de baixa renda nas instituições federais de ensino superior e técnico. Se antes desses dois eventos a tônica do debate recaía sobre ser ou não justo adotarmos esse tipo de política pública em nosso país (Feres Júnior, 2009, p. 41), com o apoio decidido dos três poderes - Judiciário, Legislativo e Executivo -, as vozes que clamavam pela rejeição das cotas quase silenciaram, dando lugar a questões relativas à performance dessas políticas.

Um levantamento realizado pelo nosso Grupo de Estudos Multidisciplinares da Ação Afirmativa (Gemaa lesp-Uerj) a partir de uma base que inclui todos os textos publicados sobre o tema nos jornais O Globo e Folha de S. Paulo entre 2001 e 2012 mostrou como se deu a evolução dos argumentos contrários às ações afirmativas de corte étnico-racial ao longo de mais de uma década. Durante esse período, dentre reportagens, artigos de opinião, editoriais, cartas de leitor etc., o jornal carioca publicou 1.054 textos lidando com essa modalidade de política, enquanto o jornal paulistano, 983, totalizando 2.037 textos. O mesmo estudo 
mostra que na cobertura midiática, as opiniões contrárias às ações afirmativas preponderaram, seja nos editoriais, colunas e opinião ou até nas reportagens ${ }^{1}$.

A análise desse corpus de textos demonstrou que os argumentos contrários às políticas de ação afirmativa racial veiculados pela grande mídia impressa brasileira se concentraram em três grupos temáticos, que estiveram presentes por todo o período de dez anos transcorridos desde a criação das primeiras políticas de cotas, em 2002-2003, até 2012 (Campos e Feres Júnior, 2013a, p. 15, 2013b, p. 16). São eles: 1) "raça e identidade nacional", que congrega argumentos em torno da ideia de que a política importa um sistema de classificação racial binário dos Estados Unidos, racializando a sociedade brasileira e violando, assim, a plasticidade das relações raciais brasileiras baseadas na "mistura", que constitui o cerne da identidade nacional (O Globo, 2003, 2009b; Pinto de Góes, 2001); 2) "Estado e cidadania", que congrega argumentos em torno da acusação de que a ação afirmativa ameaça a igualdade legal, que é a base da cidadania e do constitucionalismo democrático; e 3) "procedimentos e resultados", que congrega uma pletora de argumentos que apontam para supostos problemas de procedimentos e incapacidade de gerar resultados das políticas de ação afirmativa (Cardoso, 2003; Serra, 2004).

\footnotetext{
${ }^{1}$ Esses jornais também publicaram opiniões favoráveis, mas em menor número. Cf. Campos e Feres Júnior (2013a).
} 


\section{Gráfico 1}

Incidência de argumentos contrários às ações afirmativas nos textos dos jornais O Globo e Folha de S. Paulo (2001-2012)

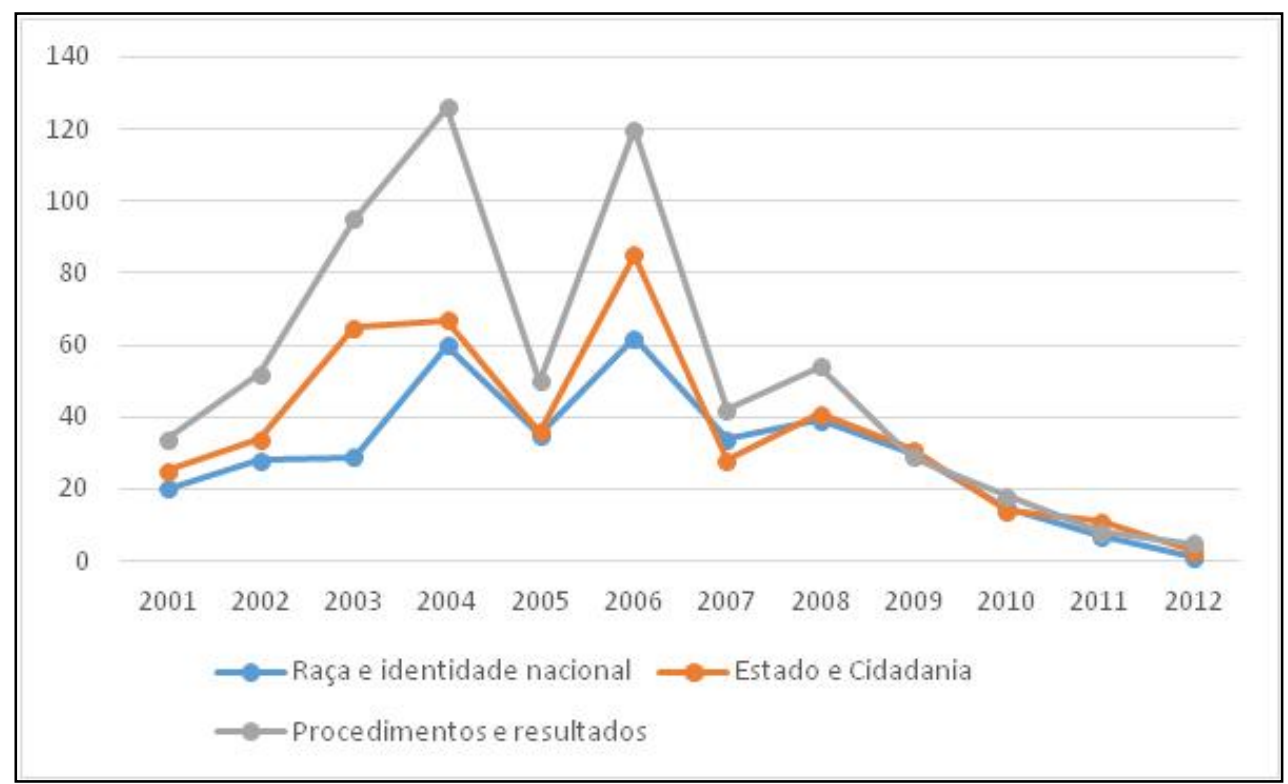

Fonte: Elaboração própria, baseada em dados da pesquisa "Ação afirmativa na grande mídia", do Grupo de Estudos Multidisciplinar da Ação Afirmativa (Gemaa).

A análise e a classificação dos argumentos presentes nesse corpus de textos permitem notar que houve momentos de pico de determinados argumentos (como, por exemplo, no ano de 2007, quando a ideia segundo a qual a ação afirmativa racializa e divide a sociedade brasileira dominou os jornais) e também de declínio acentuado (a partir de 2008, quando esse mesmo argumento perdeu importância). Hoje, no contexto pós-2012, percebe-se que os argumentos que ganham mais força são críticos aos procedimentos das ações afirmativas, isto é, dizem respeito à ideia segundo a qual tais políticas são ineficientes ou meramente paliativas.

Entre os argumentos contrários às políticas de ação afirmativa que estavam presentes antes de 2012, um dos mais contundentes é o de que a ação afirmativa terá como consequência somente o benefício de uma elite dentro do grupo de beneficiários. Traduzindo diretamente para o debate brasileiro, trata-se da acusação de que a ação afirmativa vai somente beneficiar negros ricos e de classe média. No presente artigo pretendemos mostrar que esse argumento não foi formulado originalmente no Brasil, pois apareceu anteriormente em outros lugares onde a ação afirmativa foi implantada, particularmente na Índia, país pioneiro na adoção dessas políticas, e nos Estados Unidos, exemplo mais influente e conhecido mundialmente de ação afirmativa para descendentes de africanos. Logo em 
seguida, identificamos sua apropriação pelo debate nacional, investigando sua ocorrência em uma base composta por todos os textos publicados sobre o tema da ação afirmativa nos jornais Folha de S. Paulo e O Globo. Neste artigo, apresentamos evidências da utilização insistente nos textos da grande mídia impressa do argumento de que a ação afirmativa beneficia apenas a "nata" dos grupos visados (ou, como conhecida nos Estados Unidos e na Índia, o creamy layer). Em sequência, demonstramos que essa preocupação não se baseou em evidências concretas, pois: a) as políticas de ação afirmativa de recorte racial existentes no Brasil até 2011 já eram dominantemente estruturadas para evitar o benefício dos mais privilegiados dentro do grupo de beneficiários; e b) os dispositivos da Lei Federal 12.771, aprovada em 2012, também previnem contra o mesmo fenômeno, até de maneira excessiva.

\section{O benefício da nata?}

A Índia foi o primeiro país a adotar políticas de ação afirmativa. Provisões para a criação de programas de discriminação positiva (reservation policies) em benefício de grupos desprivilegiados como os dalits e tribos "intocáveis" (scheduled castes e scheduled tribes) ${ }^{2}$ já estavam presentes na Constituição indiana de 1950 , documento promulgado logo após a independência do país. É da Índia que advém a expressão creamy layer, usada para designar coletivamente os indivíduos privilegiados pertencentes a um grupo maior de beneficiários de uma determinada política pública. Assim, a ação afirmativa é acusada desde seus primórdios de beneficiar uma camada de pessoas que supostamente já teriam vantagens competitivas na seleção para empregos ou vagas em escolas e universidades, camada essa que, portanto, prescindiria de medidas especiais como as ações afirmativas.

Com efeito, alguns acadêmicos sustentam que na Índia as políticas de ação afirmativa só têm sido capazes de propiciar importantes vantagens econômicas para uma minoria muito restrita da população-alvo (Bains, 1994, p. 85; Mendelsohn, 1999, p. 54; Sen, 2001, p. 201). Apesar de reconhecerem que a compensação discriminatória desempenha um papel simbólico e exemplar ao colocar membros desses grupos em posições políticas e sociais de destaque, eles avaliam esses efeitos simbólicos como secundários e acreditam ser mais

\footnotetext{
${ }^{2}$ Os atuais beneficiários das políticas de reserva são os Intocáveis, que receberam dos britânicos a denominação legal de scheduled castes (SCs) e representam $15 \%$ da população indiana. As tribos ou scheduled tribes (STs), grupos cujas precárias formas de subsistência em áreas florestais vêm sendo crescentemente ameaçadas pela expansão demográfica e econômica dos outros indianos, constituem $7,5 \%$ da população total do país, e as other backward classes (OBCs), demais grupos também considerados social e economicamente desprivilegiados, perfazem $52 \%$ da população. Cf. Tummala (1999, p. 497).
} 
importantes medidas que alterem de fato as circunstâncias em que vivem esses indivíduos, como sua presença nas escolas, por exemplo. Além disso, alegam que as pequenas mudanças promovidas por essas políticas nas últimas décadas mostram suas limitações e que é possível que a insistência nesse tipo de programa seja até mesmo uma estratégia para evitar o debate sobre a adoção de medidas mais drásticas de redistribuição.

Oliver Mendelsohn, por exemplo, argumenta que os dalits receberam cotas em empregos públicos as quais foram capazes apenas de beneficiar alguns indivíduos e suas famílias sem, no entanto, diminuir significativamente a pobreza que atinge o grupo. O autor alega ainda que a reserva de vagas no Legislativo, outra modalidade de ação afirmativa comum na Índia, produziu benefícios muito intangíveis e simbólicos e frequentemente se questiona o quanto os candidatos de fato representam seu grupo de origem. Além disso, Mendelsohn diz que, com o aumento da competitividade eleitoral na Índia, a população dos dalits conseguiu obter uma série de ganhos mais efetivamente por meio da votação ordinária do que dos mecanismos eleitorais compensatórios. Por fim, ele alega que a provisão de educação especial aos dalits, apesar de ter produzido resultados mais substantivos, ficou limitada à alfabetização e à educação básica. Segundo essa argumentação, quando existente, a assistência financeira aos dalits no ensino superior foi capaz de beneficiar somente os membros mais competitivos do grupo, dada a sua insuficiência de recursos para cobrir todos os gastos educacionais (Mendelsohn, 1999, p. 63).

Entretanto, essa leitura negativa não é consensual ou mesmo hegemônica naquele país. Outros pesquisadores contra-argumentam que a possibilidade de perpetuação de uma pequena elite dalit parece incomodar muito mais os membros das castas privilegiadas do que a própria comunidade. Aparentemente, o que os dalits desejam é que os mais privilegiados do grupo não percam seus elos com a comunidade e que se engajem politicamente em seu favor, convertendo as oportunidades recebidas em meios de elevar as condições de vida de todos. Alegase que o motivo pelo qual esses dalits de classes mais baixas não se sentem prejudicados pelas políticas de reserva é o fato de saberem que poucos entre eles têm o nível de instrução necessário para competir pelas reservas no emprego, no parlamento ou no Ensino Superior (Mallick, 1997, p. 345-374).

A respeito das reservas eleitorais para as scheduled tribes, por sua vez, Alistair Mcmillan defende que, ainda que o benefício para o conjunto desses grupos não seja substancial, a política conseguiu transferir recursos para uma classe média politicamente mobilizada e articulada que agora é capaz de lutar por mais direitos e inclusão de membros do seu grupo de origem (Mcmillan, 2005, p. 311). Pran Chopra (1997, p. 26) identifica nas reservation policies a capacidade de produzir 
lideranças com altos níveis de competência. Com efeito, o próprio B. R. Ambedkar ${ }^{3}$, militante dalit e presidente da comissão que redigiu a Constituição indiana, argumentava que apenas com a transformação de alguns dalits em membros da elite seria possível melhorar as condições de vida de seu grupo, pois isso faria que eles se dessem conta de seu próprio potencial ao proporcionar exemplos positivos para o grupo (Zelliot, 2005, p. 47).

Outra linha de argumentação é seguida por Ghanshyam Shah, para o qual não é plausível criticar as políticas de reserva com a alegação de que podem, por exemplo, beneficiar um dalit rico e prejudicar um brâmane pobre. Ainda que pertençam à mesma classe social, membros desses grupos não podem ser comparados: fatores culturais e diferenças de capital humano afetam suas chances de obter educação e competitividade no mercado de trabalho (Shah, 2002, p. 296314). No mesmo registro, Decanesan Nesiah acrescenta que os dalits mais educados e economicamente bem-sucedidos sofrem discriminação por conta do estigma da "intocabilidade" e da persistência do preconceito de casta (Nesiah, 1999, p. 36). Com efeito, quando perguntado se seu filho deveria ser beneficiário das políticas de reserva, Jagjivan Ram, o primeiro membro das scheduled castes a adentrar os mais altos círculos da política indiana, afirmou que, como ainda restavam algumas mesas em que seu filho não podia jantar, talvez a "intocabilidade" ainda fosse um assunto relevante, o que faz da ação afirmativa uma medida com um papel importante a cumprir (Parikh, 1997, p. 54).

\section{Creamy layer nos Estados Unidos: Thomas Sowell}

Embora tenha sido formulado na Índia, o argumento do creamy layer não ficou restrito àquele país. Ele está presente, por exemplo, nas controvérsias acerca das ações afirmativas nos Estados Unidos desde a década de 1960. Um dos principais propagandistas desse discurso no país é o economista negro norteamericano Thomas Sowell, um campeão antiação afirmativa em seu país. Sowell é titular da cátedra Milton Friedman na Universidade de Stanford e um ícone do pensamento conservador americano. Autor do livro Affirmative action around the world: an empirical study (Sowell, 2004), que é um verdadeiro manifesto contra essas políticas, Sowell deslinda uma miríade de argumentos contra políticas de ação afirmativa e tem como ponto principal a tese de que elas foram experiências fracassadas nos países que as implantaram. O livro contém um capítulo introdutório

\footnotetext{
${ }^{3}$ Bhimrao Ramji Ambedkar (1891-1956) foi um jurista, político, filósofo e economista indiano que, entre outras coisas, inspirou o movimento de renovação do budismo e foi o principal idealizador da Constituição indiana.
} 
e uma conclusão, enquanto cada um dos capítulos restantes é dedicado a um caso nacional: Índia, Malásia, Sri Lanka, Nigéria e Estados Unidos.

O principal argumento de Sowell contra a ação afirmativa é de ordem moral. Segundo ele, tais políticas se justificam assumindo a premissa de que um determinado padrão desigual de distribuição é causado por ações intencionalmente discriminatórias de um grupo contra outro. Daí ser necessária uma ação que redistribua desigualmente bens e oportunidades para compensar a falta original. $\mathrm{O}$ autor então tenta mostrar que em vários casos nacionais não há evidência sólida de história de discriminação ou vitimização dos grupos menos privilegiados. Sowell sugere que tais desigualdades podem ser produto de padrões de comportamento ou "outras diferenças" entre grupos e não de discriminação, argumento anteriormente utilizado por Friedrich von Hayek para defender a tese de que somente a aplicação universal da norma é justificável (Hayek, 1960, p. 194-195) ${ }^{4}$.

Mas esse não é o único argumento contrário. O livro é recheado deles. Há os de natureza moral, mas também outros de ordem prática e empírica, que buscam provar que a ação afirmativa é mal concebida e não funciona direito, isto é, não é capaz de produzir os resultados que almeja. Claramente decorrente do argumento moral feito pelo autor está a acusação, apresentada logo em seguida, de que as políticas de ação afirmativa acabam por beneficiar "aqueles que já são mais afortunados, produzindo pouco ou nenhum benefício para aqueles que são verdadeiramente desprivilegiados" (Sowell, 2004, p. 195). Sowell tenta mostrar que, ao falhar na prática em atingir os menos privilegiados, as políticas de ação afirmativa estariam subvertendo inteiramente seus propósitos, privilegiando os já privilegiados, o que é um delito moral capital.

Não deve nos escapar o fato de tal argumento se encaixar perfeitamente naquilo que Albert Hirschman chamou de "tese do efeito perverso", uma das três teses da retórica reacionária usadas por toda a história do Ocidente moderno para deslegitimar conquistas por direitos civis, políticos e sociais (Hirschman, 1991, p. 11-42). No caso, as políticas estariam fazendo exatamente o contrário daquilo para o qual foram propostas, daí o rótulo "efeito perverso".

Sowell afirma peremptoriamente que as políticas de reserva na Índia beneficiam majoritariamente o creamy layer (Sowell, 2004, p. 187) e que isso é explícito naquele país. Como vimos há pouco, tal opinião é controversa entre acadêmicos indianos, mas o autor furta-se a trazer essa controvérsia para as

\footnotetext{
${ }^{4}$ Hayek defende a ideia de que, dado que os seres humanos são diferentes, a aplicação de leis iguais e universais produzirá resultados diferentes, pois eles têm capacidades diferentes de usufruir os privilégios e benefícios das leis. Assim, a lei é justa porque preserva a diferença natural. $\mathrm{Na}$ passagem, o autor deixa transparecer que está pensando não somente em diferenças individuais, mas também em diferenças de grupo e etnia. Não é impossível interpretar a passagem como uma referência, ainda que velada, a diferenças de ordem racial. O mesmo pode-se dizer do texto de Sowell supracitado, particularmente por meio do uso da expressão vaga "outras diferenças".
} 
páginas de seu livro. Segundo ele, nos Estados Unidos as pessoas ainda não estão conscientes desse grave problema. A diferença se explicaria pelo fato de o sistema de castas na Índia tornar mais fácil a identificação do creamy layer, em comparação aos Estados Unidos, que não partilha de tal estrutura social. Sowell também acusa o governo norte-americano de se furtar a produzir estatísticas que comprovem o suposto fato de a ação afirmativa beneficiar os já privilegiados, mas alerta que "uma gama de fontes privadas" mostram que os "afro-americanos mais afortunados recebem uma parcela desproporcional dos benefícios da ação afirmativa naquele país" (p. 186). É interessante notar que nesse trecho Sowell não fornece qualquer pista de quais seriam essas "fontes privadas". Ainda que seu livro seja bem mais um texto para divulgação e militância do que um trabalho acadêmico, outras passagens de fato contêm algumas referências a trabalhos de especialistas. Não é o caso aqui.

\section{O creamy layer chega à grande mídia brasileira}

A primeira referência ao livro de Sowell no debate acerca da ação afirmativa travado na mídia brasileira aparece em uma reportagem da Folha de S. Paulo, assinada pelo jornalista João Batista Natali, de maio de 2004. O livro de Sowell tinha acabado de ser lançado nos Estados Unidos e, a despeito de seu título, "Livro de negro americano condena cotas", a reportagem de Natali é crítica e balanceada. Além de usar de um tom descritivo para se referir ao livro e a seu lançamento, o jornalista adverte que os casos nacionais examinados por Sowell "têm pouco a ver com o Brasil". Além de elencar algumas críticas feitas por Sowell e adversários da ação afirmativa nos Estados Unidos, o autor do texto também expõe os argumentos daqueles que são favoráveis a essas políticas naquele país.

A segunda referência encontrada em nossa base de textos dos grandes jornais ocorre em data próxima, 29 de junho do mesmo ano, mas cujo tom é completamente diverso da reportagem de Natali. Trata-se de texto de opinião intitulado "Cotas, um erro já testado", da autoria de Ali Kamel (2004c). O título já indica o conteúdo do texto, que é uma louvação ao livro de Sowell; um sumário de argumentos sacados do livro sem uma nota crítica sequer, a não ser, obviamente, às políticas de ação afirmativa. Kamel escreve de modo cartesiano, enumerando claramente argumentos, parágrafo após parágrafo. A lista é a seguinte: as ações afirmativas, uma vez criadas, tendem a se perpetuar, a despeito de promessas em contrário; elas também tendem a ser estendidas a outras categorias de beneficiários, o que constituiria um mal aos olhos de comentador e comentado; os grupos não beneficiados passam a cometer desonestidades para tentar amealhar o benefício (falsa identificação, por exemplo); os mais privilegiados dentro do grupo 
se apoderam da maior parte dos benefícios (creamy layer); "as políticas de preferências e de cotas acarretam [...] o ódio racial"; "as cotas [sic] são desnecessárias, pois as minorias já estão em trajetória de ascensão social, pelo menos nos Estados Unidos"; as cotas não tiveram nenhum impacto sobre a ascensão social dos negros; e as cotas são contraproducentes, pois grande parte dos estudantes que as utilizam não consegue terminar os cursos.

A despeito do erro de chamar as políticas de ação afirmativa nos Estados Unidos de "cotas" ${ }^{5}$, e de acusar a ação afirmativa de causar o ódio racial, a tônica do texto de Kamel recai sobre argumentos que tentam mostrar que tais políticas não funcionam bem, não alcançam as finalidades para as quais são propostas. Dentre esses argumentos, o principal é o do creamy layer, pois a acusação de que a ação afirmativa teve pouco impacto é explicada por Kamel exatamente pelo suposto fato de ela ser aproveitada por aqueles que já estão ascendendo e, portanto, dela não precisariam.

Em nossa base de dados, Kamel aparece em oitavo lugar entre os autores que mais publicaram textos acerca do assunto, com 22 peças. Acima dele temos somente Elio Gaspari (44), Demétrio Weber (41), Antônio Gois (39), Ediane Merola (37), Demétrio Magnoli (29), Miriam Leitão (28) e Fernanda da Escóssia (25). Se levarmos em conta somente os textos de caráter opinativo, sua classificação sobe. Weber, Gois, Merola e Escóssia são jornalistas, que produzem reportagens e não textos opinativos, já Gaspari é autor de textos de opinião, mas sua coluna é publicada religiosamente nos dois jornais, o que faz com que seu número seja dobrado. Assim, como autor de textos opinativos, Kamel aparece em terceiro lugar no ranking geral, empatado com Gaspari. Se levarmos em conta o fato de que tanto Leitão como Gaspari expressam geralmente opiniões favoráveis às ações afirmativas de recorte racial, concluímos rapidamente que Magnoli e Kamel são os campeões da reação a essas políticas nesses grandes jornais. O Gráfico 2 mostra a distribuição da publicação dos textos desses dois autores, todos contrários às "cotas", no período em estudo:

\footnotetext{
${ }^{5} \mathrm{O}$ uso de cotas como modalidade de política de ação afirmativa nos Estados Unidos foi declarado ilegal pela Suprema Corte no julgamento do caso Bakke, em 1978. A opinião majoritária, do ministro Powell, declara ser legal a utilização do critério raça em processos de seleção junto a outros critérios, todos com a finalidade de garantir a diversidade do corpo discente. Cf. Ball (2000) e Schwartz (1988). Mesmo no Brasil as políticas de ação afirmativa não se reduzem às cotas, que são uma de suas modalidades.
} 


\section{Gráfico 2 \\ Número de textos publicados por Demétrio Magnoli e Ali Kamel nos jornais O Globo e Folha de S. Paulo (2001-2012)}

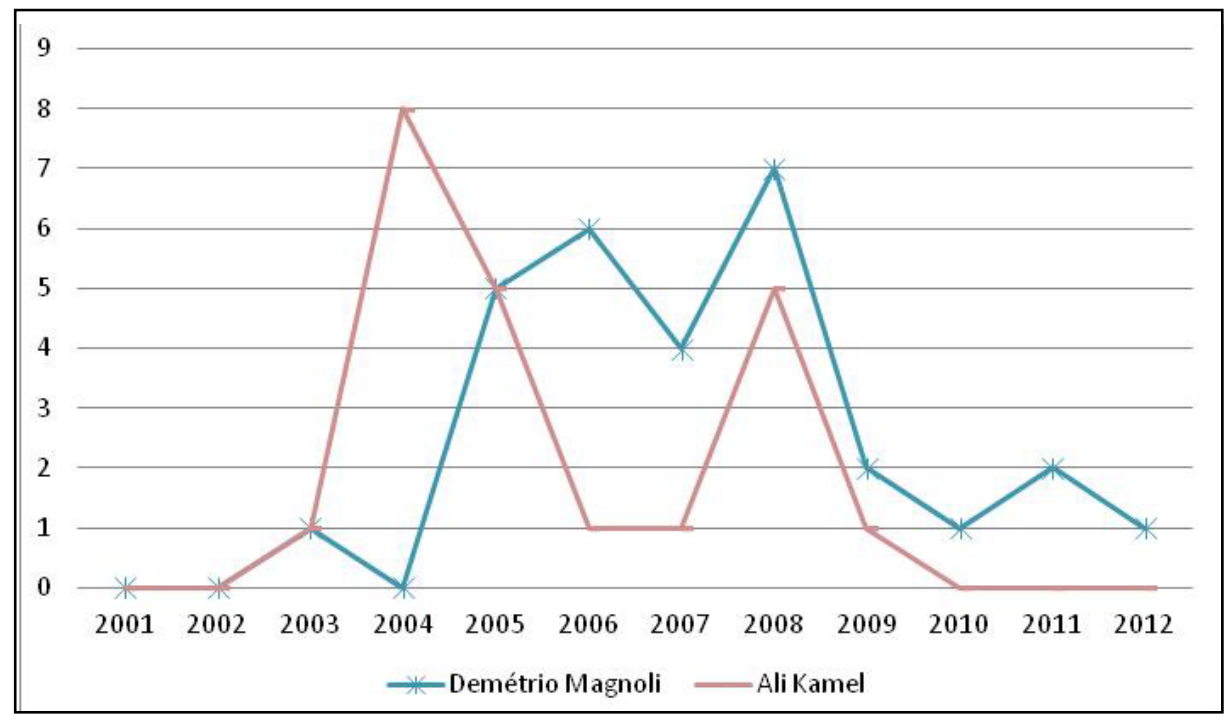

Fonte: Elaboração própria, baseada em dados da pesquisa "Ação afirmativa na grande mídia" do Grupo de Estudos Multidisciplinar da Ação Afirmativa (Gemaa).

Como podemos notar pelo gráfico, Kamel foi líder da oposição às cotas na grande mídia no começo do período, ou seja, logo depois que os primeiros programas foram aprovados em 2002-2003. A partir de 2005, Demétrio Magnoli assume esse papel, com Kamel tendo alguma participação até 2010 e depois se ausentando do debate. É preciso ser dito, contudo, que todos os 22 textos de Kamel contra as cotas apareceram em um só jornal, O Globo, enquanto Magnoli tem participação forte nos dois veículos: 15 textos em O Globo e 14 na Folha de S. Paulo ${ }^{6}$.

Devido à sua proximidade com a editoria do jornal, do qual tinha sido editor-chefe, e seu cargo dentro das Organizações Globo, não pode ser descartada a hipótese de o jornalista ter também escrito ou participado da redação de editoriais do jornal que tratavam do assunto. No mesmo período, O Globo publicou 132 editoriais com a ação afirmativa racial como tema. Entre eles, nenhum era favorável: 123 abertamente contrários, 5 ambivalentes e 4 que citavam de passagem as políticas sem proferir opinião explícita. Contudo, considerada a característica dos dados dos quais dispomos, não podemos testar diretamente a

\footnotetext{
${ }^{6}$ Hoje diretor geral de Jornalismo e Esportes, Kamel já foi jornalista, diretor da sucursal de Brasília, editor-chefe adjunto, editor-chefe e diretor de O Globo. Na época ora em exame, já havia se tornado diretor executivo de jornalismo das Organizações Globo e assinava uma coluna quinzenal no referido jornal.
} 
hipótese da participação de Kamel nos editoriais. Podemos notar, contudo, a semelhança entre as curvas de distribuição temporal dos textos publicados por ele e dos editoriais, como mostra o Gráfico 3:

\section{Gráfico 3 \\ Artigos de Ali Kamel e editoriais publicados no jornal O Globo (2001-2012)}

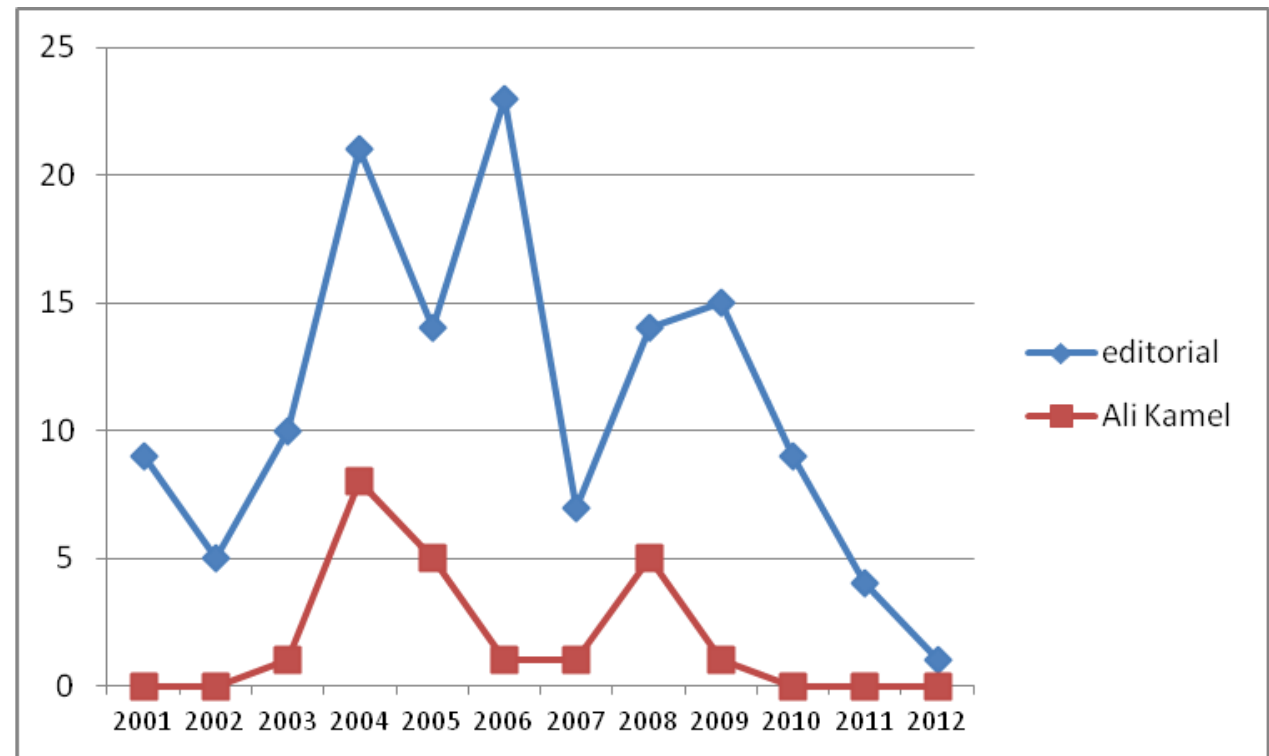

Fonte: Elaboração própria, baseada em dados da pesquisa "Ação afirmativa na grande mídia" do Grupo de Estudos Multidisciplinar da Ação Afirmativa (Gemaa).

A militância de Kamel contra a ação afirmativa de recorte étnico-racial ganhou mais visibilidade com a publicação do livro Não somos racistas: uma reação aos que querem nos transformar numa nação bicolor (Kamel, 2006), publicado por uma editora comercial com ótima distribuição nacional e anunciado em painéis de ônibus urbanos e em salas de cinema - algo incomum no mercado editorial brasileiro.

O livro traz na contracapa texto de Yvonne Maggie, acadêmica que se notabilizou pela oposição pública às $\operatorname{cotas}^{7}$, no qual Kamel é aclamado como "cientista social acostumado a fazer perguntas e a desarmar as armadilhas do óbvio, de discursos que têm pretendido se impor como discursos de verdade" e

\footnotetext{
7 Nem todos os acadêmicos brasileiros se opuseram publicamente às ações afirmativas de recorte racial. Houve vários que vieram a público defendê-las. Cf. Campos (2009). Com o passar dos anos os trabalhos acadêmicos sobre as políticas de ação afirmativa têm aumentado, atraindo inclusive jovens pesquisadores interessados no funcionamento e nos resultados concretos produzidos por esses programas.
} 
seus textos são ditos como "fonte riquíssima de informação e de discussão para pesquisadores pelo país afora".

Sowell é citado no livro de Kamel no capítulo intitulado "As cotas no mundo", cujo objetivo é mostrar, baseando-se exclusivamente no livro do autor americano, que tais políticas fracassaram mundo afora, em todos os lugares em que foram implementadas. O texto do capítulo é, na verdade, quase idêntico ao do artigo do jornal, com algumas poucas adições e supressões. Presente tanto no artigo quanto no livro está a apresentação que Kamel faz de Sowell como "um dos mais renomados intelectuais americanos" 8 .

O argumento do creamy layer aparece no livro de Kamel no capítulo "As cotas no mundo" e também no capítulo "O dinheiro que não vai para os pobres", dedicado a criticar o programa Bolsa Família e a Lei Orgânica de Assistência Social (Loas), dois programas do governo federal, o primeiro para atender famílias com renda muito baixa e o segundo para atender idosos e deficientes. Sowell é citado nesse contexto novamente para referendar o argumento de que os já privilegiados vão se beneficiar de maneira desproporcional dos programas de assistência (Kamel, 2006, p. 124).

No final de 2004, Sowell é citado outra vez em artigo de O Globo, novamente em uma referência ao argumento do creamy layer, mais uma vez em texto de Ali Kamel (2004a), endereçado nesse caso aos deputados federais brasileiros, os quais são alertados para o perigo das cotas. Um pouco menos de um mês depois da publicação desse artigo, Kamel cita de novo Sowell em texto para 0 Globo, agora para criticar livros favoráveis à ação afirmativa. O argumento do creamy layer aqui não é central, mas sim uma crítica mais genérica a essas políticas (Kamel, 2004b). No final de dezembro de 2004, seis dias depois da publicação do último texto de Kamel, o jornal publica um texto de opinião favorável escrito em coautoria por Vania Penha-Lopes, Timothy Mulholland e Amancio Paulino de Carvalho ${ }^{9}$. No artigo em questão os autores, a despeito de discordarem

\footnotetext{
${ }^{8}$ Não muito tempo depois da publicação do artigo de Kamel, O Globo publicou uma carta de leitor discordando da opinião lisonjeira dispensada a Sowell. Segundo o missivista, Sowell defende em seus artigos as seguintes ideias: "Bush não mentiu sobre as armas de destruição em massa no Iraque; a mídia (the hyena press) presta um desserviço ao denunciar a tortura infligida a soldados iraquianos, já que 'eles fazem pior'; Rodney King, cujo espancamento provocou tumultos em cidades americanas em 1992, não apanhou por ser negro, mesmo porque a polícia americana não é racista (Are cops racist?); a única maneira de evitar massacres como o de Columbine é armar toda a população; fornecer remédios gratuitos a idosos carentes é fazer a medicina do almoço grátis (free lunch medicine). Já ia me esquecendo da melhor: os negros têm QI inferior ao dos brancos devido a certos aspectos da cultura africana" (Medeiros, 2004).

9 Estudo recente mostra que a cobertura de O Globo sobre as cotas foi decididamente contrária às políticas. Contudo, diferentemente da revista Veja, que adotou uma posição contrária absoluta, passando a publicar somente textos com esse ponto de vista, O Globo deu espaço para opiniões favoráveis, ainda que quantitativamente minoritárias na cobertura (Campos e Feres Júnior, 2013b, p. 18). No dia em questão, 20 de dezembro de 2004, o artigo favorável de Penha-Lopes apareceu em seção intitulada "Cotas em debate", acompanhado de artigo também favorável mas institucional
} 
veementemente do jornalista de O Globo e acusarem o livro de Sowell de não ter fontes empíricas sólidas, concordam que as políticas de ação afirmativa podem ser capturadas por estratos mais privilegiados das minorias, como no caso dos negros nos Estados Unidos (Penha-Lopes, 2004).

O nome de Sowell volta a ser citado em 2006, em reportagem curta na qual o geneticista Sérgio Pena se retrata por não ter tomado posição contra as cotas em artigo de 2004, e cita Sowell para dizer que as cotas racializam a sociedade (Guedes e Motta, 2006). Em outubro de 2007, Sowell é citado de passagem, pela primeira vez, em artigo de Demétrio Magnoli, que, como já mostramos, tornou-se um campeão da luta contra as cotas raciais (Magnoli, 2007). O nome do autor americano apareceria mais uma vez em matéria no jornal que reproduz trechos da carta-manifesto contra as "cotas raciais" assinada por 113 acadêmicos e celebridades e entregue ao ministro Gilmar Mendes, do Supremo Tribunal Federal. A passagem da carta diz que Sowell "documenta extensamente" que as referidas políticas "não contribuíram em nada para reduzir desigualdades, mas aprofundaram o cisma racial que marca como ferro em brasa a sociedade norte-americana" (Brígido, 2008). Ou seja, ainda que não explícita, a referência à incapacidade de debelar desigualdades se conecta, nos argumentos do autor, diretamente ao argumento do creamy layer. Fechando o conjunto de textos que fazem referência ao polemista norte-americano, Demétrio Magnoli cita novamente, em março de 2012, sua "obra devastadora sobre as políticas contemporâneas de raça", mas a referência para por aí.

Assim como Kamel e Sowell, Magnoli também foi autor de livro-manifesto contra a ação afirmativa. Uma gota de sangue: história do pensamento racial (Magnoli, 2009) é mais pretensioso em seu escopo histórico e geográfico do que o trabalho de Sowell, e bem menos acadêmico em sua concepção: Magnoli oferece ao seu leitor algo em torno de 20 referências a fontes para cada capítulo da obra, muitas delas repetidas, enquanto o autor norte-americano trabalha na casa das 370 referências em média por capítulo. Há apenas uma referência a Sowell no livro de Magnoli, e ela diz respeito exatamente ao argumento do creamy layer. Magnoli usa a opinião do autor norte-americano como evidência de que na Nigéria as políticas de "equilíbrio étnico" beneficiaram os membros dos grupos que haviam deixado a zona rural e se integrado à vida urbana, isto é, elites dentro de seus respectivos grupos (Magnoli, 2009, p. 254-255).

e defensivo do então reitor da UnB, Timothy Mulholland (2004): "Tema em debate: Cotas raciais", e de artigo francamente contrário de Amancio Paulino de Carvalho (2004), professor da Faculdade de Medicina da UFRJ e diretor do Hospital Universitário Clementino Fraga Filho, no qual o autor defende que as universidades de ponta, como a USP e a UFRJ, fizeram bem em rechaçar as cotas para preservar o mérito e, assim, sua função social, que é a de produzir profissionais capacitados. 
A recepção de Sowell na Folha de S. Paulo é bem mais acanhada. Depois da referência em matéria de Natali, já comentada, Sowell aparece em entrevista curta, na qual se resumiu a acusar a ação afirmativa de produzir conflito racial e de beneficiar o creamy layer (Folha de S. Paulo, 2004). E, finalmente, seu nome é citado no texto da mesma carta-manifesto entregue ao STF, em maio de 2008, reproduzida integralmente nas páginas do jornal e já comentada por nós acima (Brígido, 2008).

Outra maneira de traçarmos o impacto desse argumento é fazê-lo diretamente, por meio do exame de sua incidência na amostra e na interação com outros argumentos. Sua distribuição temporal no universo de textos dos dois jornais está exposta no Gráfico 4:

\section{Gráfico 4}

Incidência do argumento do creamy layer nos textos publicados no jornal O Globo e Folha de S. Paulo (2001-2012)

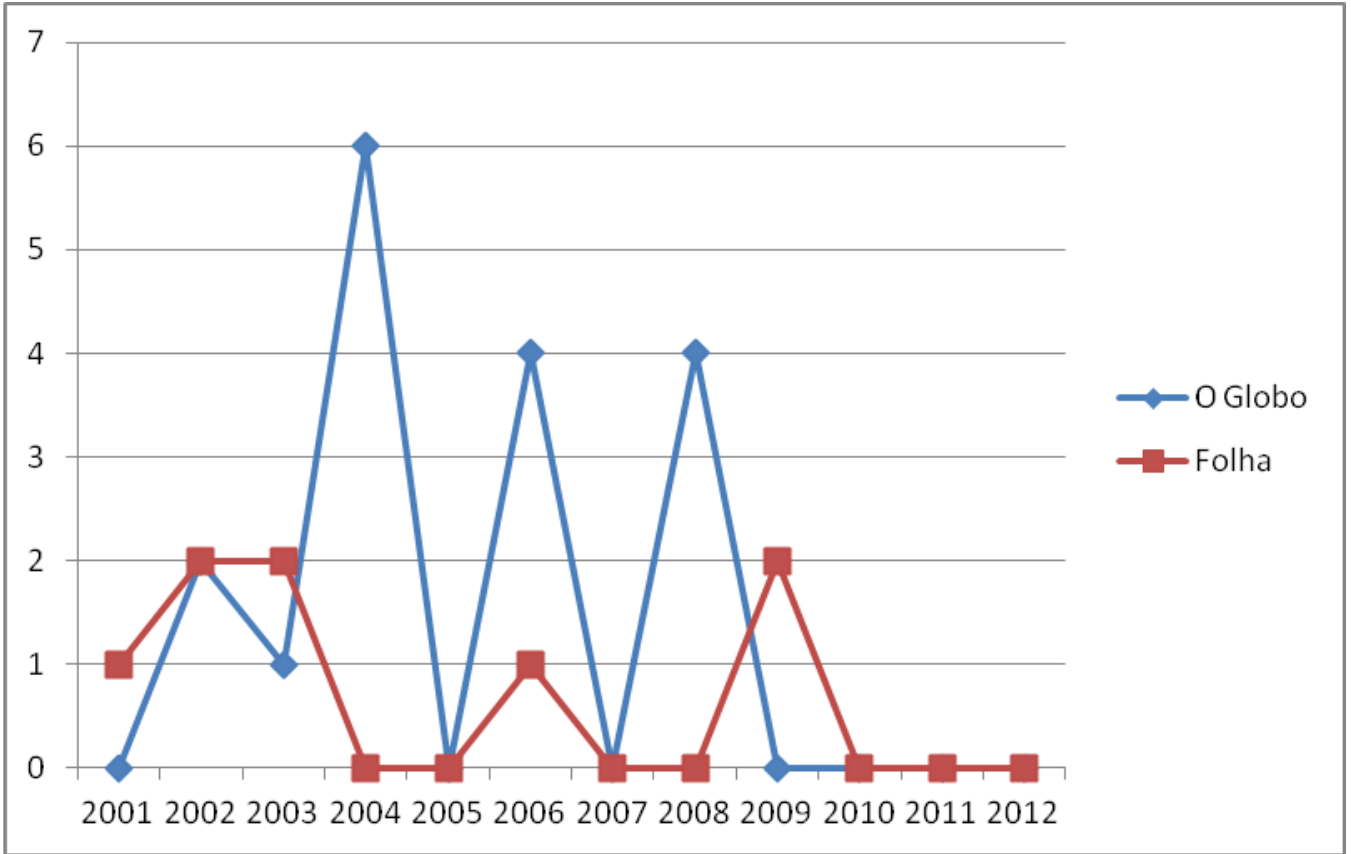

Fonte: Elaboração própria, baseada em dados da pesquisa "Ação afirmativa na grande mídia" do Grupo de Estudos Multidisciplinar da Ação Afirmativa (Gemaa).

Como se pode constatar, o uso do argumento era mais comum nos anos iniciais, diminuindo à medida que o tempo passou, e a partir de 2010 não mais apareceu nos jornais. Mais importante é notar que ele foi usado muito mais em $\mathrm{O}$ Globo do que na Folha de S. Paulo. Os três picos de ativação do argumento correspondem aos três picos de ativação do tema da ação afirmativa na cobertura 
dos jornais. Em outras palavras, quando as cotas foram mais combatidas, o argumento foi mais usado.

A maneira como o argumento aparece nas páginas de O Globo também chama atenção. O primeiro movimento de ativação atinge seu ápice em 2004, ou seja, ele se dá em grande medida em reação à criação das primeiras políticas de ação afirmativa, particularmente na Uerj e na $U_{n B}{ }^{10}$. Várias menções no ano de 2003 advêm da fala de políticos, como Ciro Gomes, Cristovam Buarque e Jefferson Péres, senador do PDT, em virtude do impacto do debate sobre o tema no Congresso Nacional. No primeiro mês de 2004 foi publicada uma reportagem na editoria "País" do jornal em que se afirmava, sem citar fontes, que "[o] governo acredita que as cotas seriam apenas um paliativo e privilegiariam um determinado número de negros e pardos" (Éboli, 2004). Naquele mesmo mês, O Globo solta o primeiro editorial utilizando o argumento do creamy layer para atacar as "cotas". Ainda nesse ano, Kamel publica dois artigos utilizando o argumento (Kamel, 2004a; 2004c) -somente no ano de 2004 o jornalista publicou nesse jornal quatro artigos contra a ação afirmativa.

Depois de um hiato em 2005, quando não foi usado, o argumento volta às páginas do jornal em 2006, agora impulsionado pela forte cobertura dada pela mídia ao caso dos gêmeos que prestaram a UnB, e um foi aceito como cotista e outro não (Seligman, 2007). A primeira referência do ano aparece em uma reportagem entusiasmada pelo fato de a UFMG ter privilegiado a criação de cursos noturnos e não cotas como solução para a inclusão social. O jornalista Itamar Mayrink, autor do texto, profere: "Um estudo da UFMG revelou que um regime de cotas raciais não aumentaria a inclusão de estudantes de baixa renda na UFMG. $O$ levantamento mostrou um peso maior para as diferenças socioeconômicas". Não há, contudo, qualquer informação sobre esse estudo, se há disponibilidade pública de resultados, quem o fez, em que condições, metodologia etc. A UFMG foi de fato uma das universidades que mais tempo resistiu à adoção de políticas de inclusão de real efeito ${ }^{11}$. Alguns meses depois, o argumento aparece em texto de Peter Fry e

\footnotetext{
${ }^{10}$ Em 2003, entrou em vigor a Lei Estadual no 4.151, que instituiu reserva de vagas para o ingresso de alunos pretos e pardos nas universidades estaduais do Rio de Janeiro, Universidade Estadual do Rio de Janeiro (Uerj) e Universidade Estadual do Norte Fluminense (Uenf). Na Universidade do Estado da Bahia (Uneb) a política foi criada por meio da deliberação número 196/2002 do Conselho Universitário. Em 2003 os conselhos universitários da Universidade do Estado da Bahia (Uneb) e da Universidade de Brasília (UnB) também aprovaram a adoção de cotas. Nos anos seguintes outras leis estaduais e resoluções de conselhos universitários foram responsáveis pela ampla disseminação de medidas similares em universidades de todo o país, até que a aprovação da Lei Federal 12.771 tornou obrigatória a reserva de vagas para pretos, pardos, indígenas, alunos de escola pública e de baixa renda nas instituições federais de ensino superior e técnico. Isso promoveu certa homogeneização dessas políticas nas universidades federais, enquanto as estaduais permanecem regidas por leis locais ou por resoluções universitárias.

11 A UFMG não adotou cotas sociais ou raciais até 2009, quando adotou um sistema de bônus que dava um adicional de $10 \%$ na nota do vestibular para alunos oriundos da escola pública e $5 \%$ para autodeclarados pretos e pardos, sistema esse que já havia sido adotado pela USP com parcos
} 
Ivonne Maggie, em meio a uma série de ataques virulentos contra as cotas, entre eles a acusação de que estão destruindo a identidade nacional brasileira ao implantar um sistema binário de reforço de identidades raciais e que constituem o germe do fascismo: "é o ovo de serpente de uma nação pautada em diferenças 'étnicas/raciais'" (Fry e Maggie, 2006). O argumento do creamy layer reaparece logo depois em mais um artigo de Kamel.

Seguindo padrão similar de ativação, o argumento desaparece em 2007 para ressurgir em 2008, agora sob o esteio do manifesto anticotas. Sua primeira aparição no ano se dá na cobertura feita por O Globo da entrega do Manifesto ao STF. Na manchete de primeira página lê-se: "Grupo entrega ao STF manifesto contra cotas". O subtítulo chama atenção ao apoio de "celebridades": "Assinada por 113 pessoas, entre elas dona Ruth [Cardoso], Caetano e João Ubaldo, carta acusa sistema de estimular ódio racial". A despeito do uso do argumento mais virulento entre todos, o do ódio racial, já no primeiro parágrafo do texto que segue a manchete encontramos o argumento do creamy layer: "o documento afirma que os vestibulares que adotam o mecanismo das cotas acabam privilegiando estudantes de classe média "arbitrariamente classificados como negros". Logo em seguida, o texto dá a palavra à antropóloga Yvonne Maggie, liderança do movimento anticotas, que em poucas palavras diz que, além de dividir o país entre brancos e negros nas universidades, "as cotas favorecem uma pequena elite". Em sequência, nas páginas internas do jornal, seguindo o lead, encontramos os excertos do manifesto, entre eles a passagem: "as cotas raciais proporcionam privilégios a uma ínfima minoria de estudantes de classe média". E por fim, como se não bastasse ter repetido o mesmo argumento três vezes na mesma peça jornalística, ele é escolhido para ilustrar a foto do ministro Gilmar Mendes recebendo a carta das mãos de seus portadores. A legenda diz: "O PRESIDENTE DO STF, Gilmar Mendes, com o documento levado pela comissão: cotas privilegiam estudantes de classe média 'arbitrariamente classificados como negros', critica o grupo" (Brígido, 2008) ${ }^{12}$.

Ainda no mês de maio O Globo publica editorial no qual cita o manifesto dos 113 "intelectuais" para afirmar que as cotas "são elitistas, pois beneficiarão apenas uma franja da classe média, média/baixa, mantendo a grande massa de pobres, independentemente da cor, à margem do ensino" (O Globo, 2008). No mês seguinte é a vez de Ali Kamel voltar à carga, agora em invectiva direta contra o

resultados. A partir de 2011, a universidade mudou para uma fórmula matemática polinomial, para adequar o processo de seleção ao uso das notas do Enem. Para mais informações, ver <http://vestibular. brasilescola.com/noticias/ufmg-altera-formula-bonus-para-cotistas-novestibular.htm>.

12 Pouco depois foi encaminhado ao Supremo Tribunal Federal o "Manifesto em defesa da justiça e constitucionalidade das cotas". Os mais de 740 signatários enfrentaram claramente o argumento de Sowell e defenderam que o propósito da ação afirmativa é promover a igualdade de representação, isto é, contribuir para que o número dos estudantes negros nas universidades públicas seja proporcional à presença dos negros na população brasileira. 
programa de ação afirmativa da UnB, dizendo que "as cotas da UnB beneficiam apenas os alunos mais ricos" (Kamel, 2008). Em julho, O Globo publica mais um editorial atacando as cotas, usando novamente o argumento do creamy layer ( $O$ Globo, 2008). Em setembro, reportagem informa que pesquisa encomendada pelo partido Democratas (DEM) mostra que $75 \%$ da população brasileira apoia as cotas sociais e somente $11 \%$, as raciais. Agora a voz é dada ao senador do DEM, Demóstenes Torres, então presidente da Comissão de Constituição e J ustiça (CCJ) e principal responsável pela ADPF impetrada no Supremo Tribunal Federal pelo mesmo partido contra as políticas de ação afirmativa de recorte racial. Demóstenes profere: "Existem famílias negras ricas. Os filhos dessas famílias, que puderam estudar em boas escolas, também terão direito às cotas? Eu entendo que não devem ter".

A cobertura da Folha de S. Paulo não ecoou tanto o argumento do creamy layer, se comparada ao seu par carioca. Há de notar alguns fatos pitorescos como o aparecimento do argumento em uma entrevista dada ao jornal por Frederik de Klerk, líder conservador sul-africano que, não obstante, contribuiu para o fim do regime do Apartheid. O que chama atenção não é o fato de De Klerk lançar mão do argumento, mas de a Folha de $\mathrm{S}$. Paulo não fazer uma referência às credenciais conservadoras do entrevistado.

O que podemos concluir do uso do argumento do creamy layer na cobertura jornalística? Certamente, que ele foi um argumento importante, primeiro, por ter sido articulado pelos campeões de publicação de artigos contra as cotas, Ali Kamel e Demétrio Magnoli; segundo, por ele aparecer até em reportagens, de maneira naturalizada e sub-reptícia, como mostramos; e, terceiro, por ele ter tido um papel importante, particularmente na cobertura da entrega do Manifesto anticotas ao STF feita por O Globo, jornal abertamente contrário às políticas (Campos e Feres Júnior, 2013b).

Isso nos conduz a uma outra pergunta, que é crucial para o presente artigo: será que essa crítica se aplica às políticas de ação afirmativa no Brasil, como acusam Kamel, Magnoli e os editoriais de O Globo, entre outros? Nossa resposta é negativa. Mostraremos na seção seguinte, "Ação afirmativa no chão de fábrica", que tal acusação é leviana se levarmos em conta o grosso das políticas de ação afirmativa de viés racial adotadas pelas universidades públicas brasileiras, estaduais e federais, de 2003 a 2012, ou seja, desde a implementação dos primeiros programas à decisão unânime do STF em favor de sua constitucionalidade e à aprovação da Lei no 12.711 que regulamenta o sistema de cotas em todas as universidades federais, ambas ocorridas em 2012. Mostraremos também que o regime produzido pela nova lei para as federais tem provisões contra o creamy layer, ainda que essas mesmas medidas tenham um resultado incerto. 


\section{Ação afirmativa no chão de fábrica}

Quem se informa acerca da ação afirmativa somente por meio da grande imprensa corre o risco de adquirir uma visão muito distorcida dessas políticas. Enquanto na mídia o debate se dava em torno da questão da adoção de cotas étnico-raciais no Brasil, de 2002 até pelo menos 2009 (ver o Gráfico 5), as políticas espalhavam-se pelo país de maneira impressionantemente rápida. Os levantamentos periódicos produzidos pelo Grupo de Estudos Multidisciplinares da Ação Afirmativa (Gemaa), do lesp-Uerj, permitem acompanhar os processos de implementação das políticas de ação afirmativa nas universidades estaduais e federais brasileiras. Tais estudos mostram que essas políticas se alastraram mais rapidamente entre as universidades estaduais. Em 2012, 86\% delas (31/37) já adotavam alguma política de ação afirmativa (social, racial ou ambas). No Gráfico 5 podemos observar a série temporal de adoção de programas de ação afirmativa nessas universidades:

\section{Gráfico 5}

Adesão das universidades estaduais às ações afirmativas por ano

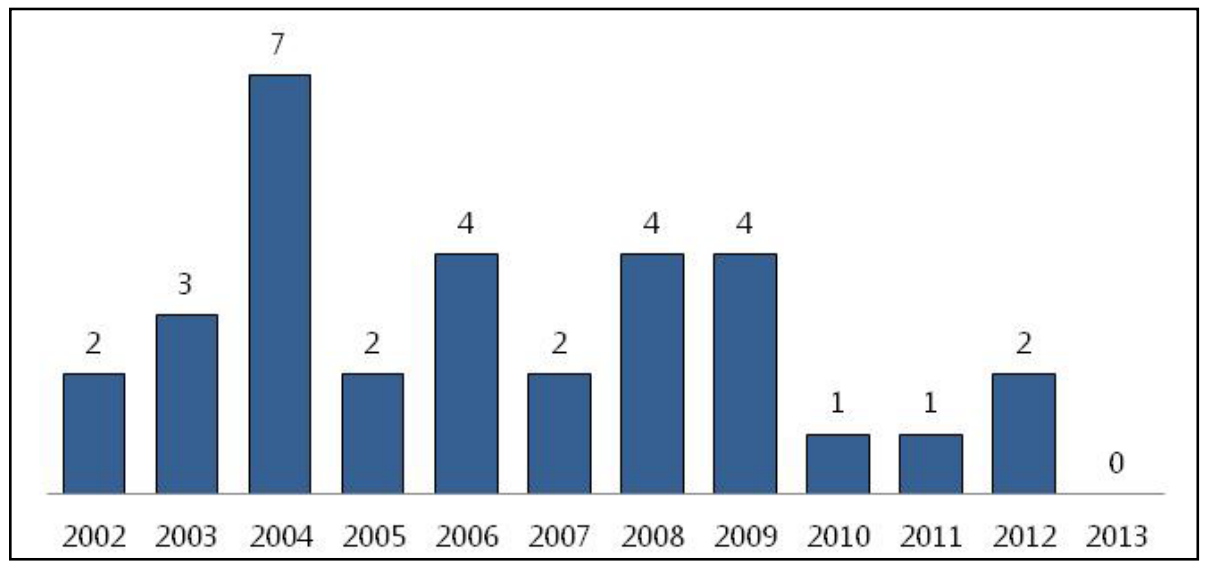

Fonte: Elaboração própria, baseada em dados da pesquisa "Evolução temporal e impacto da Lei $n$ o 12.711 sobre as universidades federais" do Grupo de Estudos Multidisciplinar da Ação Afirmativa (Gemaa).

Nas federais o padrão foi distinto. Como indica o Gráfico 6, elas começaram a adotar as políticas um ano mais tarde que seus pares estaduais. Até o ano de 2007, o ritmo de adoção de ações afirmativas foi mais lento. O pico verificado em 2008 explica-se pelo fato de ter sido esse o ano em que muitas dessas instituições aderiram ao Reuni (Reestruturação e Expansão das Universidades Federais), plano do governo federal que, entre outras coisas, condicionou a transferência de recursos para as universidades federais à adoção de políticas de inclusão no 
vestibular. O segundo pico deu-se em 2013, quando a presença das ações afirmativas nas universidades federais saltou de $70 \%$ para $100 \%$. Esse foi o ano da implantação da Lei de Cotas, que tornou obrigatória a política para todas as unidades de ensino superior federais. O Gráfico 6 mostra a evolução temporal da adoção de programas de ação afirmativa nas universidades federais:

\section{Gráfico 6}

Adesão das universidades federais às ações afirmativas por ano

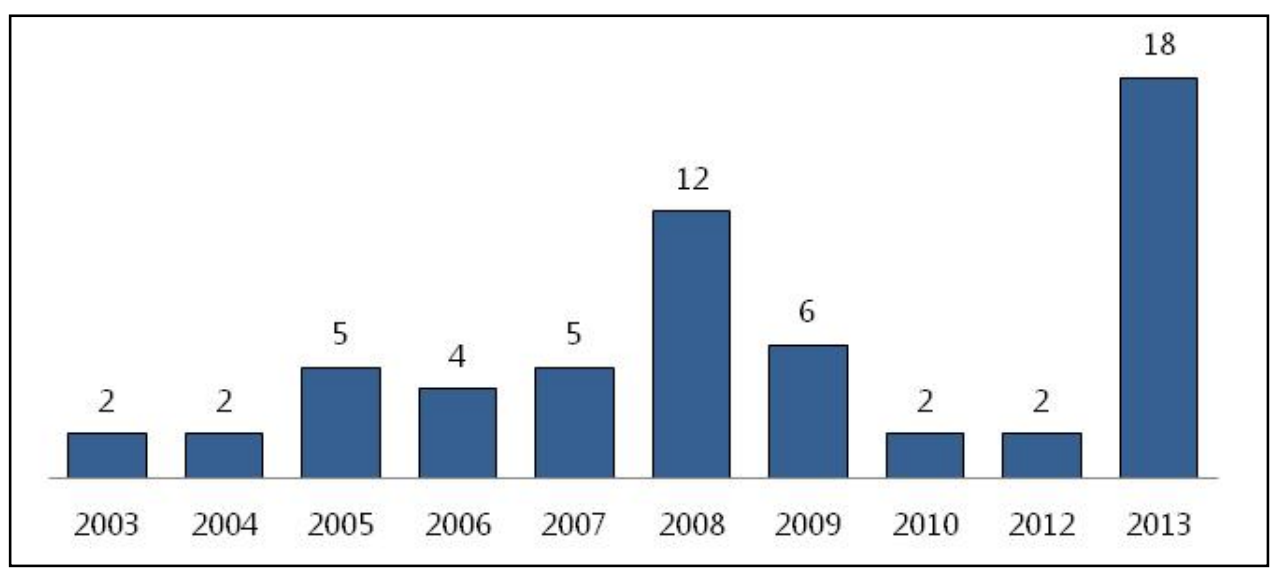

Fonte: Elaboração própria, baseada em dados da pesquisa "Evolução temporal e impacto da Lei no 12.711 sobre as universidades federais" do Grupo de Estudos Multidisciplinar da Ação Afirmativa (Gemaa).

Como indica o Gráfico 6, 18 universidades federais haviam resistido à implantação de programas de ação afirmativa até 2012.

Para melhor avaliarmos a parcialidade da cobertura nos jornais analisados no que toca à utilização do argumento do creamy layer com intuito de deslegitimar a adoção de políticas de ação afirmativa racial no Brasil, não é suficiente mostrar que programas desse tipo de fato existem em profusão, mas também identificar quem são seus beneficiários. Aqui também a cobertura midiática pode induzir a cidadã ou o cidadão ao erro. Quase a totalidade de textos publicados acerca das políticas de ação afirmativa na grande mídia trata de sua modalidade étnico-racial, particularmente as "cotas para negros". A realidade do "chão de fábrica" até às vésperas da implantação da Lei de Cotas, contudo, é bem diferente, como mostra o Gráfico 7: 
Gráfico 7

Número de universidades estaduais com ação afirmativa de acordo com o tipo de beneficiário (2012)

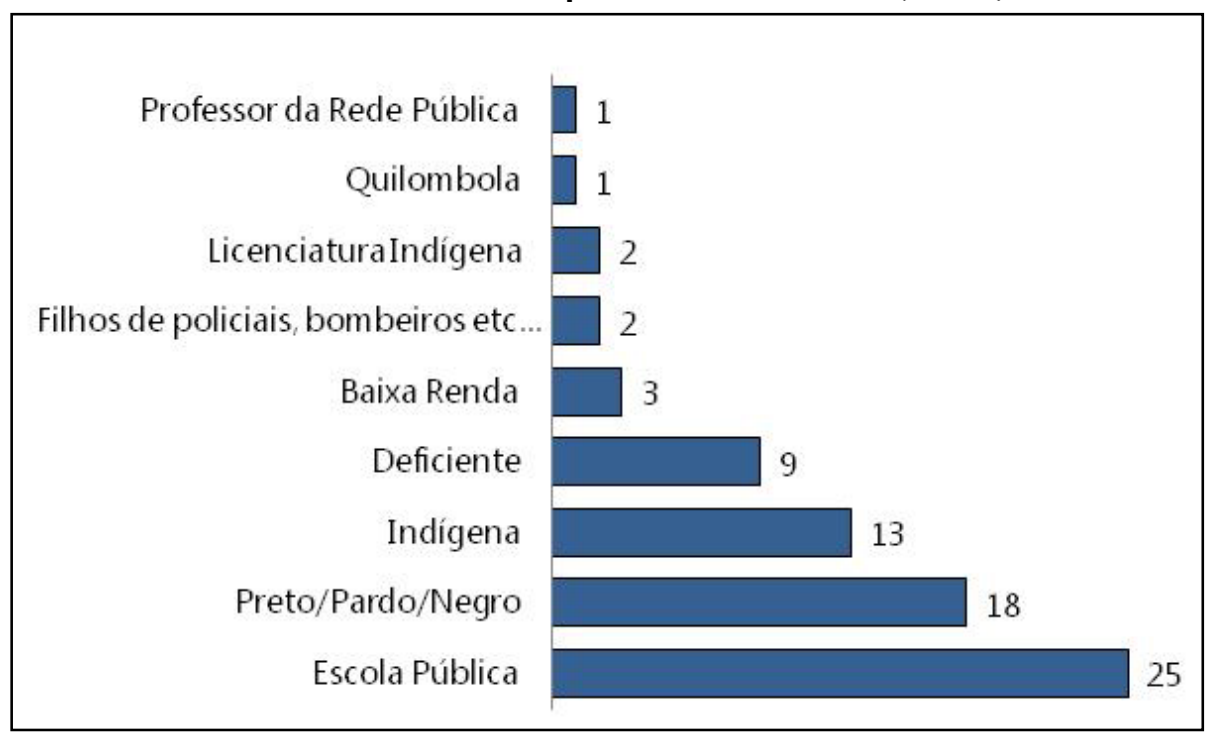

Fonte: Elaboração própria, baseada em dados da pesquisa "A ação afirmativa no ensino superior brasileiro" do Grupo de Estudos Multidisciplinar da Ação Afirmativa (Gemaa).

O padrão das universidades federais, até 2012 - ano imediatamente anterior à entrada de vigência da Lei que homogeneizou os critérios - , é similar, como revela o Gráfico 8: 


\section{Gráfico 8 \\ Número de universidades federais com ação afirmativa de acordo com o tipo (2012)}

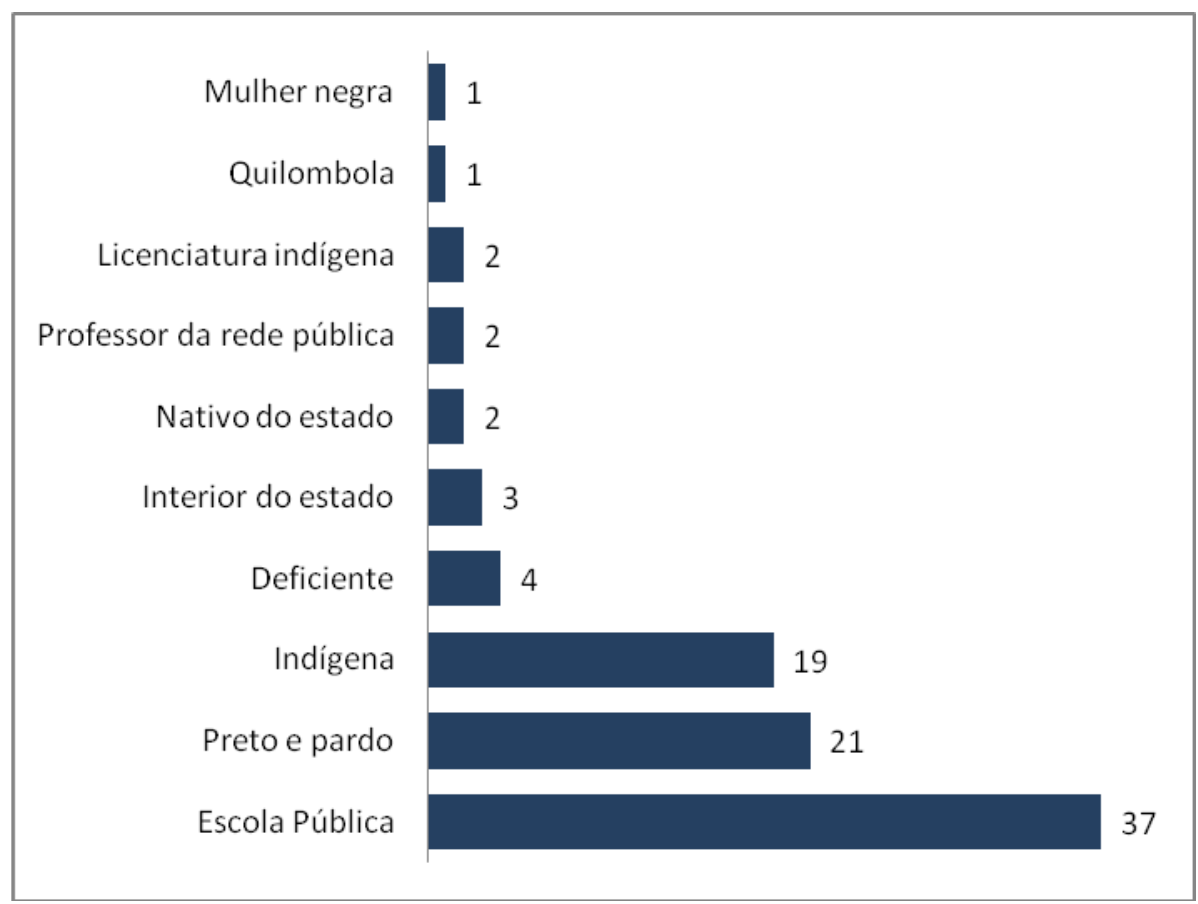

Fonte: Elaboração própria, baseada em dados da pesquisa "A ação afirmativa no ensino superior brasileiro" do Grupo de Estudos Multidisciplinar da Ação Afirmativa (Gemaa).

Como se pode notar, a variante mais comum de política de ação afirmativa era, até 2012, escola pública, tanto nas universidades estaduais quanto nas federais. A proporção de universidades com cotas para alunos de escola pública em relação a cotas para negros nas estaduais é $25 / 18$, ou seja, $140 \%$, enquanto nas federais essa proporção alcançava 37/21, isto é, $176 \%$, em 2012 . Esse é um dado muito importante, pois é de conhecimento geral que a categoria "escola pública" é adotada nos programas de ação afirmativa menos como instrumento de valorização do ensino público médio e fundamental (um provável efeito colateral benigno), e mais como proxy da renda familiar. A razão é simples. No Brasil de hoje é muito difícil contar com a comprovação de renda como critério para políticas públicas, pois muitos trabalhadores estão ainda no setor informal, ou seja, não têm qualquer comprovação de renda. Além disso, a proporção de pessoas que declaram imposto de renda ainda é pequena, particularmente nos níveis de renda mais baixos, e muita gente subdeclara. Em suma, uma política que adota declaração de renda como requisito para qualificar beneficiários corre o risco grande de errar o alvo e 
beneficiar um grande número de free riders-em outras palavras, de redundar em proveito de algum creamy layer. O critério "escola pública" é bem mais consistente, pois famílias com baixo rendimento não têm condições de colocar os filhos em escolas particulares e são, assim, forçadas a matriculá-los em escolas públicas ${ }^{13}$. Há de fato algumas escolas públicas de qualidade no país, mas elas são muito poucas se comparadas à massa do ensino público, e concentradas em algumas poucas cidades, como o Rio de Janeiro. Assim, podemos concluir que, até 2012 , tanto nas universidades estaduais como nas federais, a maioria dos programas de ação afirmativa, aqueles para alunos de escolas públicas, distribuíam vagas de maneira a evitar os privilégios de um eventual creamy layer.

Mas não podemos parar por aqui, pois os textos dos jornais, como já dissemos, tratam da ação afirmativa de recorte racial, e é contra ela que a acusação pesa mais, inclusive por meio do uso da fonte Thomas Sowell. Portanto, é preciso verificar se nessa modalidade de ação afirmativa o argumento do creamy layer não seria minimamente verossímil. Para responder a essa questão, analisaremos primeiro a realidade anterior à aprovação da Lei de Cotas, que alterou sensivelmente os programas de ação afirmativa em boa parte das universidades públicas, e, logo após, a realidade criada pela aplicação da Lei.

Se tomarmos as políticas de ação afirmativa para pretos, pardos e/ou negros adotadas até 2012 nas universidades públicas, federais e estaduais, contamos 40 casos. Desse total, 36 tinham algum critério adicional que condicionava a renda do beneficiário, ou seja, 90\% delas. Trinta universidades adotavam o critério "escola pública" (que, como já mostramos, é um proxy de renda), cinco, o critério "renda" diretamente e uma, a combinação dos dois. Em outras palavras, somente quatro universidades, 10\%, não tinham provisão qualquer sobreposta ao critério étnico-racial, como mostra a Tabela 1:

\footnotetext{
13 Mesmo levando em conta a heterogeneidade de escolas fundamentais e médias públicas e privadas no Brasil, que é grande, o desempenho médio de cada categoria em testes como o Pisa demonstra haver uma diferença significativa da qualidade do ensino. Estudo recente da OCDE traz a seguinte passagem: "In Brazil, about $13 \%$ of 15 -year-old students go to a private, independent school. On average, private schools show better performance in PISA. While their students overwhelmingly come from advantaged families, the performance advantage is apparent even after accounting for socio-economic status. For the more affluent families, private schools - which provide access to better educational resources, better physical infrastructure, and have lower studentteacher ratios - are associated with better learning outcomes". Ver <http://www.oecd.org/pisa/keyfindings/PISA-2012-results-brazil.pdf>.
} 
Tabela 1

Critérios de corte socioeconômico dos beneficiários das ações afirmativas raciais

\begin{tabular}{|l|c|c|}
\hline Critérios de corte & No & \% \\
\hline Escola pública & 30 & 75,0 \\
\hline Renda & 5 & 12,5 \\
\hline Ambos & 1 & 2,5 \\
\hline Nenhum & 4 & 10,0 \\
\hline Total & 40 & 100,0 \\
\hline
\end{tabular}

Fonte: Elaboração própria, baseada em dados da pesquisa "A ação afirmativa no ensino superior brasileiro" do Grupo de Estudos Multidisciplinar da Ação Afirmativa (Gemaa).

Todas as cinco universidades que adotavam critério de renda instituíram o valor de 1,5 salário mínimo per capita de renda familiar como limite para qualificar candidatos para as cotas. Em suma, da maneira como as ações afirmativas se implantaram até 2012, a ameaça das políticas redundarem em benefício de um creamy layer, ou seja, de uma suposta classe média negra, como dizem vários artigos de jornal, era muito pequena. Isso porque as políticas desenhadas de maneira muito diversa em universidades espalhadas por todo o país tinham em sua maioria provisões para prevenir que isso ocorresse: o uso do critério de limite de renda, ou de um proxy, a escola pública.

Aqui é importante fazer um parêntese de caráter interpretativo, que deve ficar como sugestão para futuras pesquisas. O movimento para a criação de programas de ação afirmativa no Brasil foi, em grande medida, encabeçado por militantes dos movimentos negros, e apoiado por militantes do movimento e por parte da esquerda democrática. Não houve, contudo, um movimento em prol da inclusão universitária de alunos de escola pública paralelo à mobilização do movimento negro pelas cotas. Ou seja, se no final do processo o número de programas para alunos de escola pública superou em praticamente $50 \%$ os programas para negros, isso deve ser lido mais como uma resposta das universidades às pressões do movimento negro para a criação de cotas para negros do que propriamente como uma aceitação passiva de suas demandas.

Estudo que tem como base todos os textos contrários à ação afirmativa de recorte racial mostra que o argumento de que "classe importa mais do que raça" para políticas de caráter redistributivo foi o quarto mais usado, com 122 ocorrências. Ou seja, a ideia de que ações afirmativas sociais resolveriam o problema da desigualdade de oportunidades entre brancos e não brancos no Brasil, e que, portanto, as "cotas para negros" são desnecessárias, quando não danosas, é frequentemente defendida por pessoas que se opõem às políticas de recorte racial, 
inclusive por algumas de inclinação progressista - tomando aqui por progressista aquele que é a favor da intervenção do Estado na economia e nas relações sociais. Então, uma hipótese que pode ser levantada em estudos futuros é a de que as universidades públicas, em grande medida lugares onde o pensamento progressista é majoritário, tenham sido parcialmente permeáveis às demandas do movimento negro, e, muitas vezes, mesmo não criando cotas para negros, acabaram por implantar cotas para alunos de escolas públicas. E mais, a preocupação com o creamy layer parece tão forte que, mesmo quando criaram cotas para negros, tomaram o cuidado de condicioná-las ao baixo rendimento dos beneficiários.

É necessário ainda examinarmos a situação criada pela nova Lei e tentar avaliar se ela cria condições para que as vagas sejam ocupadas pelos setores mais privilegiados entre os beneficiários. Antes de tudo, é preciso compreender como funciona a Lei no 12.711. Transcrevemos seus dois artigos principais:

Art. 1ำ As instituições federais de educação superior vinculadas ao Ministério da Educação reservarão, em cada concurso seletivo para ingresso nos cursos de graduação, por curso e turno, no mínimo 50\% (cinquenta por cento) de suas vagas para estudantes que tenham cursado integralmente o ensino médio em escolas públicas.

Parágrafo único. No preenchimento das vagas de que trata o caput deste artigo, 50\% (cinquenta por cento) deverão ser reservados aos estudantes oriundos de famílias com renda igual ou inferior a 1,5 salário mínimo (um salário mínimo e meio) per capita.

[...]

Art. 3 Em cada instituição federal de ensino superior, as vagas de que trata 0 art. $1^{\circ}$ desta Lei serão preenchidas, por curso e turno, por autodeclarados pretos, pardos e indígenas, em proporção no mínimo igual à de pretos, pardos e indígenas na população da unidade da Federação onde está instalada a instituição, segundo o último censo do Instituto Brasileiro de Geografia e Estatística (IBGE).

De acordo com o texto da lei, para candidatar-se às cotas, os estudantes devem seguir combinações diferentes de três procedimentos distintos: 1) é preciso comprovar que estudou todo o ensino médio em escola pública; 2) é necessário autodeclarar-se pertencente à etnia indígena ou de cor preta e parda; e 3) apresentar comprovação de renda no caso daqueles que concorrem às vagas para baixa renda.

A Figura 1 descreve de maneira mais esquemática o funcionamento da Lei: 
Figura 1

Diagrama de distribuição de vagas segundo a Lei 12.771

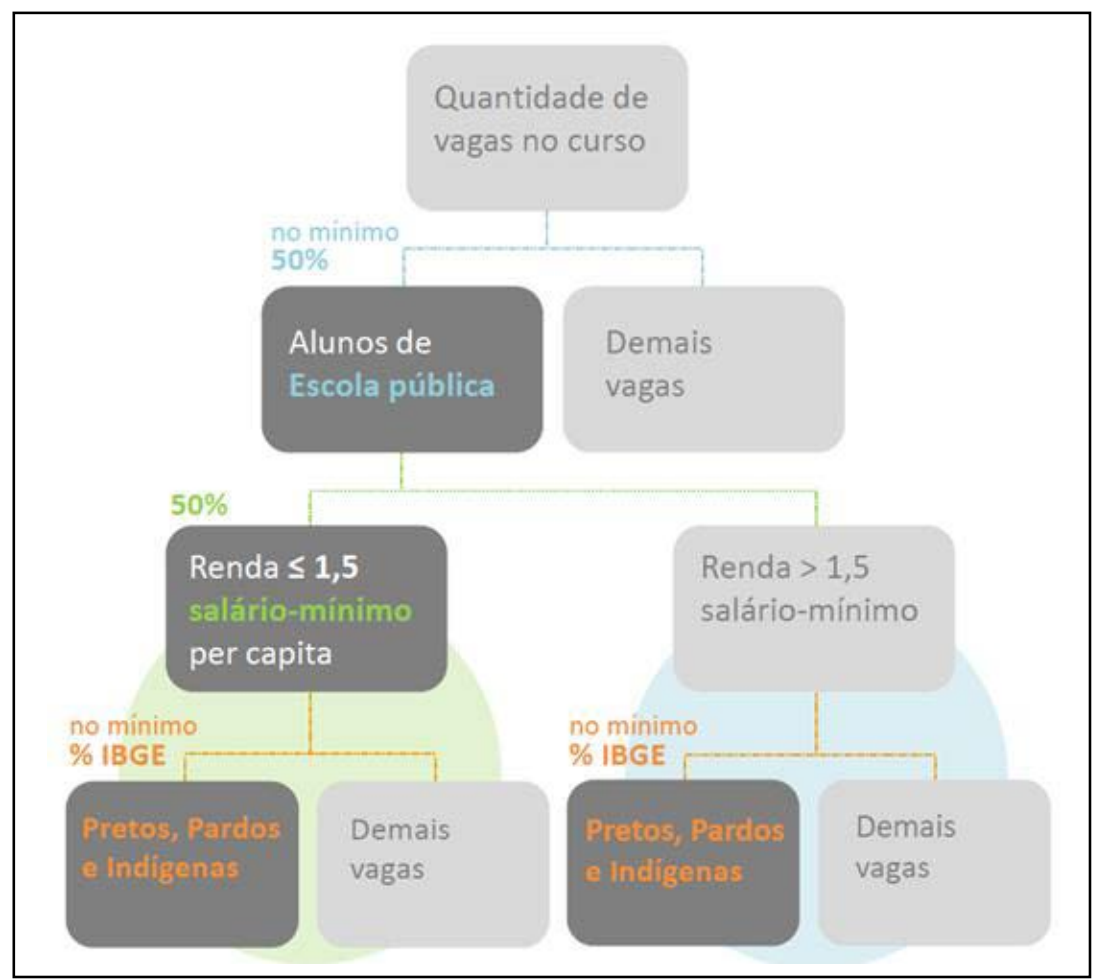

Fonte: Ministério da Educação.

Como podemos concluir, a maneira como a Lei aloca vagas garante que dos $50 \%$ das vagas reservadas, $25 \%$ sejam destinadas a alunos de baixa renda. Ou seja, se assumirmos que a variável que determina o privilégio relativo dentro do grupo de beneficiários é a renda, então essa provisão evita que o total dos benefícios seja canalizado para aqueles com maior renda entre os beneficiários. $\mathrm{Na}$ verdade, da maneira como está desenhada, a Lei garante vagas tanto para os "brancos pobres" (renda familiar abaixo de 1,5 salário mínimo per capita) quanto para os pretos, pardos e indígenas pobres, segundo o mesmo critério de renda e a proporção desses grupos na população de cada estado. Ademais, podemos argumentar que mesmo os pretos, pardos e indígenas oriundos das escolas públicas cujas famílias têm uma renda familiar superior a 1,5 salário mínimo per capita são sub-representados nas carreiras mais concorridas de nossas universidades públicas e, portanto, mereceriam ser beneficiários de uma política de ação afirmativa ${ }^{14}$.

\footnotetext{
${ }^{14}$ Se levarmos em consideração a questão simbólica, como apontado por alguns autores indianos e norte-americanos, a política se justifica a despeito do critério econômico, pois a existência de role models beneficiaria a todo o grupo discriminado.
} 
É preciso ressaltar que o fato de a escola pública funcionar como um proxy de renda, isto é, como uma barreira institucional à captura da maior parte do benefício pela elite econômica dos grupos beneficiados, distorcendo assim a finalidade da política, depende de circunstâncias contextuais que estão sujeitas ao câmbio histórico. Se houver um retorno da classe média à escola pública, ou mesmo se as escolas públicas de qualidade começarem a se multiplicar, tal critério se tornará menos operacional no que toca evitar o acesso do creamy layer ao benefício.

Por fim, a combinação de dois critérios de renda, o proxy "escola pública" e a marca de 1,5 salário mínimo de renda familiar per capita, pode gerar uma estrutura de oportunidades desigual para as quatro categorias de beneficiários. A avaliação das consequências reais dessa política é de grande interesse acadêmico e público, e está ainda por ser feita.

\section{Conclusão}

Como mostramos acima, o argumento do creamy layer foi primeiramente formulado fora do Brasil, primeiro no contexto indiano e depois nos Estados Unidos. Thomas Sowell, que o adotou para falar da própria Índia, estendendo-o também para outros casos nacionais, é um de seus defensores mais loquazes. Notamos que os especialistas indianos sobre o assunto estão longe de ter qualquer consenso seja sobre aspectos empíricos, isto é, se os benefícios são realmente abiscoitados pelos indivíduos mais privilegiados dos grupos beneficiados, seja sobre a questão normativa de se, no cômputo geral, as políticas devem ou não ser adotadas pelo conjunto dos benefícios que proporcionam.

Também detectamos a recepção do argumento no debate acerca da ação afirmativa no Brasil, focando o seu eco na grande imprensa. Nesse corpus textual nota-se a penetração de Sowell como fonte legitimadora do argumento, e o ativismo do jornal $\mathrm{O}$ Globo, particularmente de alguns de seus articulistas, notadamente Ali Kamel e Demétrio Magnoli, na sua difusão. Em seguida, analisamos dados empíricos acerca dos programas implantados no Brasil, a fim de testar a adequação do argumento ao caso brasileiro. A conclusão, em uma palavra, é de que ele não procede.

Se o argumento do creamy layer não descrevia bem o que acontecia com os programas de ação afirmativa no Brasil antes da aprovação da Lei, ele tampouco pode ser facilmente aplicado sobre a realidade da ação afirmativa nas federais sob a nova Lei. É claro que os resultados reais da aplicação da Lei, assim como das políticas anteriormente em voga, ou mesmo dos programas das estaduais, ainda carecem de avaliação cuidadosa, que seja feita a partir de dados empíricos 
advindos dessas universidades. Nota-se, baseado nas informações que hoje temos sobre o funcionamento dos programas, que eles contêm, em sua imensa maioria, provisões contra o creamy layer, o que indica que os argumentos amplificados pela mídia foram, em grande medida, especulações sem base na realidade das políticas de ação afirmativa no Brasil - adotaram a crítica feita por um publicista conservador norte-americano, Thomas Sowell, à ação afirmativa na Índia como se fosse verdade absoluta, aplicável a todo tipo de ação afirmativa, no mundo todo, ou mesmo extensível a outras políticas públicas, como o programa Bolsa Família.

A Lei de Cotas, hoje em processo de implantação nos sistemas de ensino médio e superior federais, contém, como já mostramos, provisões contra o creamy layer. Ela implica, contudo, a combinação de dois critérios de renda, um direto, o limite de 1,5 salário mínimo de renda familiar per capita, e outro indireto, a categoria proxy "escola pública", o que pode gerar resultados inesperados. Uma avaliação de qualidade acerca dos efeitos desses programas é fundamental para que estes possam cumprir de maneira eficiente a finalidade à qual se destinam, que é a inclusão de parcelas marginalizadas da população nas oportunidades de ensino, superior e médio, oferecidas pelas instituições públicas de nosso país. Para que isso ocorra é preciso não vaticínios apocalípticos infundados, formulados por publicistas conservadores, mas que as universidades franqueiem o acesso aos dados de seus programas ao público.

João Feres Júnior - Instituto de Estudos Sociais e Políticos (I esp), Universidade do Estado do Rio de Janeiro (Uerj). E-mail: <jferes@iesp.uerj.br>.

Verônica Toste Daflon - Escola de Ciência Política, Universidade Federal do Estado do Rio de Janeiro (Unirio). E-mail: <veronicatoste@iesp.uerj.br>.

\section{Referências bibliográficas}

Alberto, L. "Tema em discussão: estatuto racial". O Globo, 8 jan. 2007.

BaINS, R. S. Reservation policy and anti-reservationists. New Delhi: B.R. Publishing Corporation, 1994.

BALL, $\mathrm{H}$. The Bakke case: race, education, and affirmative action. Lawrence, Kan.: University Press of Kansas, 2000.

BRÍGIDO, C. "Grupo entrega ao STF manifesto contra cotas". O Globo, 1 maio 2008

CAMPOS, L. A. "Entre dissensos e consensos: cientistas sociais e a controvérsia pública das cotas raciais no Brasil". Dissertação de Mestrado em Sociologia e Antropologia. Universidade Federal do Rio de Janeiro, UFRJ, Rio de Janeiro, 2009. 
CAMPOS, L. A.; Feres JÚNIOR, J. "A Folha de S. Paulo e as ações afirmativas: dez anos de cobertura (2001-2011)". In: Textos para discussão Gemaa, no 3, Rio de Janeiro, 2013a, p. 119.

. "O Globo e as ações afirmativas: dez anos de cobertura (2001-2011)". In: Textos para discussão Gemaa, no 2, Rio de Janeiro, 2013b, p. 1-18.

Cardoso, M. C. "Frustrações". O Globo, 2 jun. 2003.

Carvalho, A. P. "Tema em debate: Cotas raciais". O Globo, 20 dez. 2004.

Chopra, P. An Overview. In: PANAndiker, V. A. P. (ed.). The politics of backwardness reservation policy in India. New Delhi: Konark Publishers PVT LTD, 1997.

ÉвOLI, E. "Governo desiste de instituir cotas raciais por MP". O Globo, 22 jan. 2004.

FERES JÚNIor, J. "Ação afirmativa: política pública e opinião". Sinais Sociais, vol. 3, n 8 , p. 3877, 2009.

FolHA DE S. PAULo. "Ações provocaram violência, diz autor". Editorial, 16 maio 2004. <http://www1.folha.uol.com.br/fsp/mundo/ft1605200409.htm>.

"Manifesto anticotas: cidadãos anti-racistas contra as leis raciais". Editorial, 14 maio 2008. <http://www1.folha.uol.com. br/fsp/cotidian/ff1405200807.htm>.

FRY, P.; MAGGIE, Y. "Política social de alto risco". O Globo, 11 abr. 2006.

Guedes, C.; MotTA, A. A. "Reserva de vagas: Professor alerta para risco de se fomentar o racismo". O Globo, 10 fev. 2006.

HAYEK, F. A. V. The constitution of liberty. Chicago: University of Chicago Press, 1960.

HIRSCHMAN, A. O. The rhetoric of reaction: perversity, futility, jeopardy. Cambridge, Mass.: Belknap Press of Harvard University Press, 1991.

Kamel, A. "Aos congressistas, uma carta sobre cotas". O Globo, 16 nov. 2004a.

"Combater a pobreza, esquecer as cores". O Globo, 14 dez. 2004b.

. "Cotas, um erro já testado". O Globo, 29 jun. 2004c.

. "A Constituição, segundo Tarso". O Globo, 25 jan. 2005.

. Não somos racistas : uma reação aos que querem nos transformar numa nac ,ão bicolor. Rio de Janeiro: Editora Nova Fronteira, 2006.

. "Tribunais raciais". O Globo, 24 jun. 2008.

MAGNOLI, D. "Fábrica do racismo". O Globo, 4 out. 2007.

. Uma gota de sangue: história do pensamento racial. São Paulo: Contexto, 2009.

. "Heraldo, a cor e a alma". O Globo, p. 7, 1 mar. 2012.

MALLICK, R. "Affirmative action and elite formation: an untouchable family history". Ethnohistory, vol. 44, n² 2, p. 345-374, 1997. 
JOÃO FERES JÚNIOR; VERÔNICA TOSTE DAFLON

MCMILLAN, A. Standing at the margins: representation and electoral reservation in India. New Delhi: Oxford University Press, 2005.

Medeiros, C. "Cartas dos Leitores". O Globo, 26 set. 2004.

MendeLSOHN, O. "Compensatory discrimination for India's untouchables". Law in Context, vol. 15, n², p. 51-79, 1999.

Mulholland, T. "Tema em debate: Cotas raciais". O Globo, 20 dez. 2004.

NESIAH, D. Discrimination with reason? The policy of reservations in the United States, India and Malaysia. Oxford: Oxford University Press, 1999.

O GLoвo. "Risco racial". Editorial, p. 6, 30 dez. 2003.

. "Tema em discussão: Cotas raciais". Editorial, p. 6, 18 maio 2008.

. "Brasileiro aprova cota universitária para pobres". Editorial, p. 12, 2 set. 2009a.

. "DNA do racismo". Editorial, p. 6, 22 set. 2009b.

PARIKH, S. The politics of preference: democratic institutions and affirmative action in the United States and India. Michigan: The University of Michigan Press, 1997.

Penha-Lopes, V. "Tema em debate: Cotas raciais". O Globo, 20 dez. 2004.

PINTO DE Góes, J. R. "Cotas raciais e políticas afirmativas". O Globo, 14 dez. 2001.

SCHWARTZ, B. Behind Bakke: affirmative action and the Supreme Court. New York: New York University Press, 1988.

Seligman, F. "UnB substitui envio de foto de cotistas por entrevista". Folha de S. Paulo, 2 out. 2007.

SEN, A. Desigualdade reexaminada. Rio de Janeiro: Record, 2001.

SerRA, E.G. "Tema em discussão: reforma universitária". O Globo, 19 ago. 2004.

SHAH, G. Caste and democratic politics in India. New Delhi: Permanent Black, 2002.

SowELL, T. Affirmative action around the world: an empirical study. New Haven: Yale University Press, 2004.

TUmmaLA, K. K. "Policy of preference: lessons from India, The United States, and South Africa". Public Administration Review, vol. 59, n 6, p. 495-508, 1999.

Zeluiot, E. From untouchable to dalit: essays on the Ambedkar Movement. New Delhi: Manohar Publishers, 2005.

\section{Resumo}

A nata e as cotas raciais: genealogia de um argumento público

O presente artigo trata do argumento do creamy layer, segundo o qual uma dada política pública tende a favorecer mais os indivíduos já privilegiados dentro do grupo de beneficiários. 
Tal argumento lança sobre a política a pecha de ineficiência, quando não de perversidade. Traçamos aqui brevemente a origem histórica do argumento na índia, sua adoção por parte dos opositores à ação afirmativa nos Estados Unidos e, logo em seguida, sua recepção no Brasil. Usamos como fonte o universo de textos publicados sobre cotas raciais pelos jornais Folha de S. Paulo e O Globo. A investigação mostra que (1) o argumento foi incorporado no Brasil em grande medida pela recepção das ideias de Thomas Sowell, economista conservador norte-americano, (2) que por seu turno usou a Índia como exemplo de país que adotou políticas que privilegiaram um creamy layer, ainda que (3) no debate indiano a acusação de benefício dos privilegiados esteja longe de ser consensual. Por fim, mostramos que, a despeito de o argumento ter sido usado para combater as cotas no Brasil, as políticas reais implantadas em nosso país até 2012 tinham dispositivos explícitos para prevenir o benefício dos mais privilegiados, o que lança por terra o argumento do creamy layer.

Palavras-chave: ação afirmativa; políticas públicas; creamy layer; grande mídia; Thomas Sowell

\section{Abstract \\ Affirmative action and the creamy layer argument: the genealogy of a public debate}

This article is about the creamy layer argument, according to which the better-off individuals in a social group targeted by a public policy tend to rip a disproportionate part of the benefits provided by this same policy. Such argument has been used to accuse the policy of inefficiency if not of perversity. Our chief aim here is to verify how this argument came to appear in Brazil's public debate on affirmative action and how it was rearticulated in this new context. Using a combination of genealogy and reception studies methodology, we show (1) that the argument was received in Brazil through the reception of Thomas Sowell's writtings on affirmative action in the US; (2) that Sowell used India's affirmative action as the chief example of a policy tainted by the creamy layer effect; and (3) that, ironically enough, in the Indian debate this diagnosis is far from consensual. Finally we show that despite the fact that this argument was often employed to criticize the use of racial quotas in Brazil, the actual affirmative action programs implemented until 2012 adopted criteria that prevent the creamy layer effect. The data sources used for studying each context were different. For Brazil, we analyzed all texts on affirmative action published by newspapers Folha de S. Paulo and $\mathrm{O}$ Globo until 2012. For India and the United States, we reviewed the academic literature on the topic.

Keywords: affirmative action; public policies; creamy layer; big media; Thomas Sowell 